\title{
Hangar utility simulation as a traffic flow density scenario in Giwangan Market Yogyakarta
}

\author{
Marni Astuti*, Yasrin Zabidi, Prasidananto NS \\ Departement of Industrial Engineering Sekolah Tinggi Teknologi Adisutjipto \\ Email Korespondensi : *stta_marni@yahoo.co.id
}

\begin{abstract}
Giwangan Market as a fruit and vegetable wholesale market needs to be evaluated, organized and improved in the services. Currently, its development has undergone many changes. The hangar, which is the main block for loading and unloading fruits and vegetables, has shifted its function in several places. With the addition of semi-permanent buildings on the sides of hangars, the loading and unloading area are reduced and the entry and exit routes for vehicles are not functioning properly. $86 \%$ of vehicles with a tonnage of 2000 - $5000 \mathrm{~kg}$ that entered the Giwangan market were in the market for an average of 89.9 minutes. It is because the vehicle is not only loading and unloading but also selling in the market. So that other vehicles cannot load and unload. This study aims to measure the system performance which is estimated from the average actual travel time and the loading and unloading time of vehicles in the system. The alternative of rearranging hangar used is based on the development plan of the Giwangan Market Management Office. The simulation model has been verified and validated. The first rearrangement scenario is that all traders are moved to a new location (slaughterhouse). Second, the flow in and out of the hangar is one-way. Thus, the average vehicle in the system becomes 54.44 minutes and the hangar utility is $16.13 \%$ as an indicator that the hangar performance can be improved by increasing the number of vehicles capable of loading and unloading.
\end{abstract}

Key Words : Performance System, Market Giwangan, Loading and Unloading

\section{Pendahuluan}

Pasar sebagai salah satu sentra perekonomian masyarakat menjadi sangat penting mendapatkan perhatian. Sama halnya di dalam melaksanakan suatu kegiatan, perlu adanya evaluasi dan perbaikan untuk meningkatkan kualitas, produktivitas dan kinerja suatu kegiatan. Pembenahan tidak hanya pada penampilan fisik atau desain kios-kios yang ada, tetapi menyangkut semua aspek yang selama ini menghambat kemampuan pasar tradisional[1]. Pasar sebagai salah satu sentra perekenomian akan berkembang sangat cepat. Apabila tidak ada peraturan yang jelas dalam pengelolaan pasar, akan mengakibatkan perkembangan pasar tidak sesuai dengan peruntukkannya. Salah satu variabel utama dalam Evaluasi Pasca Huni adalah aspek aksesibilitas yang sangat vital dalam mengukur keberhasilan suatu bangunan memenuhi tujuan perancangannya[2]. 
Hanggar yang menjadi blok utama dalam pasar Giwangan merupakan sentra tempat bongkar muat buah dan sayur dari luar pasar Giwangan dalam jumlah besar. Sisi-sisi hanggar yang semula berfungsi sebagai tempat bongkar muat, berjalannya waktu mengalami pergerseran fungsi di beberapa tempat. Sisi utara dipergunakan untuk berjualan oleh pedagang partai besar. Pedagang-pedagang kecil banyak menempati areal sekitar hanggar sehingga mengakibatkan alur keluar masuk kendaraan semakin sempit. Produktivitas hanggar sebagai tempat bongkar muat berkurang baik dari jumlah maupun kecepatan.

Kompleksitas tersebut mengisyaratkan diperlukan suatu alat analisis berupa model simulasi untuk mengevaluasi sistem tersebut[3]. Dari hasil simulasi sistem saat ini, dikembangkan rancangan skenario penataan ruang yang ada di pasar Giwangan. Skenario berfungsi untuk melihat alternatif-alternatif perbaikan fungsi dari hanggar dan interaksi terhadap jalur lalu lintas dan tempat parkir. Produktivitas bongkar muat dipengaruhi oleh ketersediaan alat[4]. Penelitian ini menyajikan suatu pemodelan simulasi untuk pergerakan kendaraan menuju hanggar dan waktu melakukan bongkar muat sehingga dapat menggambarkan produktivitas hanggar. Dewasa ini, simulasi telah menjadi suatu hal yang sangat penting. Berbagai penelitian dan kajian dilakukan dengan menggunakan metode simulasi sebagai salah satu teknik untuk memecahkan masalah[5]. Simulasi dengan menggunakan pendekatan pemodelan menggunakan software ProModel. Ukuran performansi sistem yang diestimasi dari model simulasi tersebut adalah ratarata waktu tempuh aktual kendaraan-kendaraan di dalam sistem tersebut.

Evaluasi lalu lintas pasar akibat berkurangnya lebar efektif jalan[6] menjadi kegiatan penting untuk meningkatkan kualitas pelayanan pasar. Jalan yang merupakan tempat keluar masuk kendaraan dipergunakan sebagai tempat parkir, sehingga akan mengakibatkan terjadi kemacetan. Maka dari itu, perlu adanya tambahan fasilitas pelayanan yang dapat mengurangi antrian atau untuk mencegah timbulnya antrian. Antrian timbul disebabkan oleh kebutuhan akan layanan melebihi kemampuan (kapasitas) pelayanan atau fasilitas layanan, sehingga pengguna fasilitas yang tiba tidak bisa segera mendapat layanan disebabkan kesibukan layanan[7]. Waktu tunggu yang tinggi berdampak merugikan pada kepuasan pelanggan[8]. Simulasi yang dikembangkan pada penelitian ini untuk mengukur performansi sistem yang diestimasi dari model simulasi yaitu rata-rata waktu tempuh aktual kendaraan-kendaraan di dalam sistem tersebut[9].

Penelitian ini dimotivasi oleh kebutuhan pihak pengelola pasar Giwangan untuk menata ulang pasar dan mengembalikan fungsi hanggar sebagai tempat utama bongkar muat buah dan sayur dalam volume besar.

\section{Metodologi Penelitian}

Penelitian ini dikembangkan dengan menggunakan pendekatan simulasi untuk meningkatkan produktivitas hanggar dan arus keluar masuk dalam pasar Giwangan. Data yang dibutuhkan untuk mengembangkan model simulasi adalah data primer yang diperoleh dari sumber secara langsung dengan observasi pada pasar Giwangan. Data-data berupa waktu kedatangan kendaraan, jumlah kedatangan kendaraan berdasarkan laporan retribusi, waktu bongkar muat di hanggar, persentase pedagang yang melakukan bongkar muat, input dan output aktual dan kebijakan manajemen pengelola pasar.

Tahapan penelitian ini pada gambar 1, sebagai berikut :

1. Uji Distribusi Data

Berguna untuk menentukan distribusi dari data-data yang akan digunakan sebagai input untuk membuat sebuah model.

2. Pembuatan Activity Cycle Diagram (ACD)

Diagram yang menggambarkan interaksi antar objek dalam suatu sistem.

3. Perancangan Model Sistem Real

Membuat layout model simulasi yang diharapkan dapat mewakili sistem yang sebenarnya.

4. Verifikasi 
Model digunakan untuk memeriksa kesalahan dan ketidakkonsisten, memeriksa hasil output yang masuk akal, dan melihat animasi tingkah laku yang benar

5. Validasi

Langkah untuk mengetahui apakah hasil simulasi model sesuai atau sudah mendekati sistem nyatanya.

6. Replikasi

Pengulangan menjalankan model agar diperoleh hasil statistik yang merupakan estimasi akurat mengenai parameter yang diuji.

7. Perancangan Model Alternatif Usulan

Membuat alternatif penyelesaian masalah dengan beberapa alternatif.

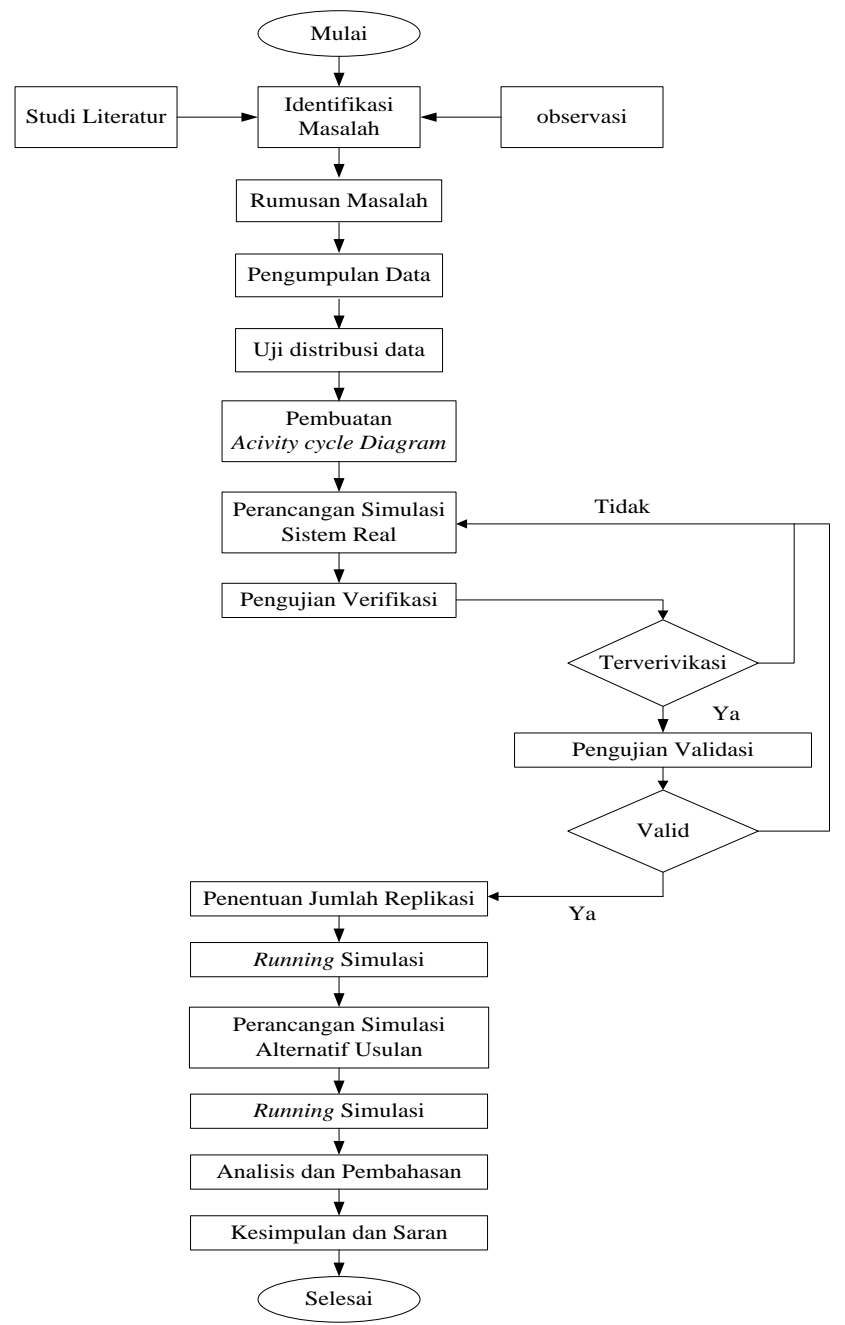

Gambar 1. Diagram Alir Penelitian 


\section{Hasil Penelitian dan Diskusi}

Dari metodologi penelitian yang telah disampaikan pada sub bab 3, model dan analisis alternatif dilakukan untuk mencapai tujuan dari penelitian ini.

\subsection{Operasi Sistem dan Deskripsi Proses}

Pasar Giwangan beroperasi selama 24 jam. Aktivitas Hanggar sebagai tempat bongkar muat dimulai pada pukul $12.00-16.00$ WIB. Jumlah kendaraan yang masuk rata-rata 168 kendaraan, yang terdiri dari beban $1000-2000 \mathrm{~kg}, 2000-5000 \mathrm{~kg}$ dan $5000-7000 \mathrm{~kg}$. Sistem dimulai dari pintu masuk pasar menuju Hanggar untuk bongkar muat dan meninggalkan pasar melalui pintu keluar pasar. Gambar 2 berikut menunjukkan layout pasar Giwangan.

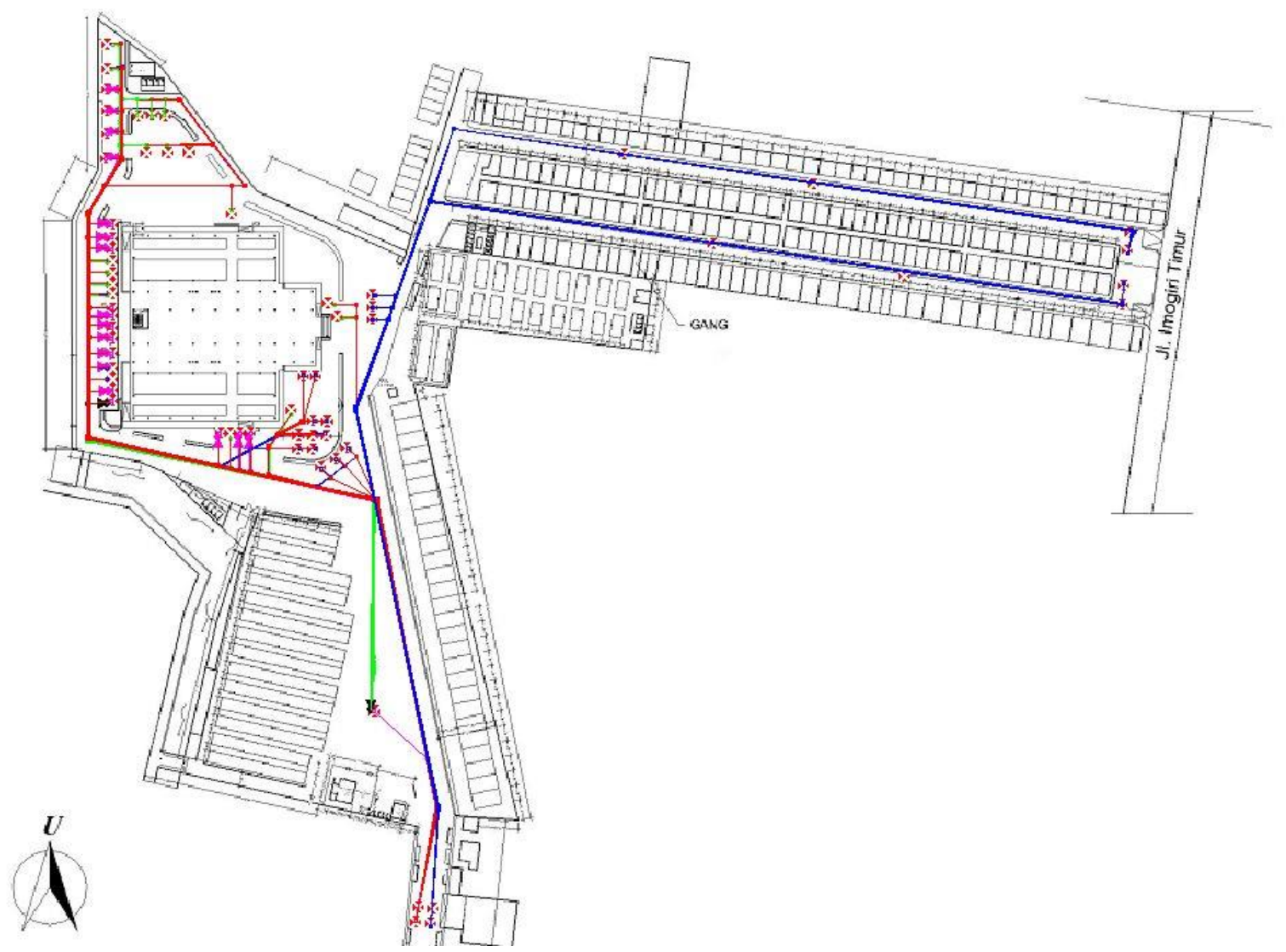

Gambar 2. Peta Layout Pasar Giwangan

\subsection{Pengumpulan Data dan Pengolahan Data}

Data yang dikumpulkan dari pengamatan sistem langsung adalah data waktu kedatangan kendaraan, dan waktu bongkar muat di Hanggar. Tabel 1 berikut menunjukkan data yang telah dikumpulkan dan telah diuji distribusi dengan menggunakan Statfit pada Promodel 7.5.

Tabel 1. Uji Distribusi Data

\begin{tabular}{cccc}
\hline & \multicolumn{3}{c}{ Hasil Uji Distribusi } \\
\cline { 2 - 4 } Kegiatan & Kendaraan & Kendaraan & Kendaraan \\
& Tonase & Tonase & Tonase \\
& $1000-2000 \mathrm{~kg}$ & $2000-5000 \mathrm{~kg}$ & $5000-7000 \mathrm{~kg}$ \\
\hline
\end{tabular}




\begin{tabular}{cccc}
\hline Proses loading & Beta & Pearson 6 & Lognormal \\
Proses unloading & - & Pearson 6 & Triangular \\
Kedatangan & Exponential & Exponential & Exponential \\
\hline
\end{tabular}

\subsection{Activity Cycle Diagram}

Gambar 3 menunjukkan pergerakkan entity dan aktivitas reources yang berada dalam sistem pasar Giwangan. Kendaraan dan jenis muatan yang masuk menuju Hanggar. Apabila Hanggar penuh maka kendaraan akan menuju areal parkir. Setelah Hanggar ada yang kosong, kendaraan menuju Hanggar dan melakukan bongkar muat.

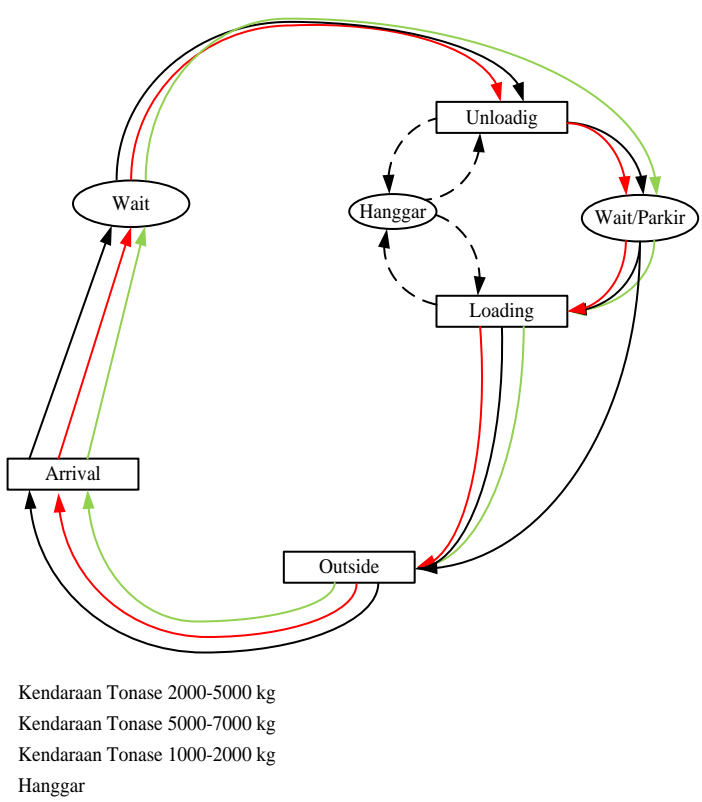

Gambar 3. Activity Cycle Diagram

3.4 Perancangan Model Sistem Riil

Model simulasi dijalankan dengan menggunakan Software ProModel 7. Pada gambar 4 yang merupakan Output dari ProModel terdiri dari banyaknya kendaraan yang masuk ke dalam pasar Giwangan, rata-rata waktu kendaraan berada di areal parkir (waktu menunggu menggunakan Hanggar), dan utilitas tempat bongkar muat Hanggar. 


\begin{tabular}{|c|c|c|c|c|c|c|c|c|}
\hline $\begin{array}{l}\text { Location } \\
\text { Name }\end{array}$ & $\begin{array}{r}\text { Scheduled } \\
\text { Hours }\end{array}$ & Capacity & $\begin{array}{r}\text { Total } \\
\text { Entries }\end{array}$ & $\begin{array}{r}\text { Average } \\
\text { Minutes } \\
\text { Per Entry }\end{array}$ & $\begin{array}{r}\text { Average } \\
\text { Contents }\end{array}$ & $\begin{array}{r}\text { Maximum } \\
\text { Contents }\end{array}$ & $\begin{array}{r}\text { Current } \\
\text { Contents }\end{array}$ & \& Util \\
\hline --------- & --------- & ------ & ------ & ---------- & --------- & -------- & & ------ \\
\hline layout & 8.5 & 1 & 0 & 0.000000 & 0 & 0 & 0 & 0.00 \\
\hline arrival & 8.5 & 999999 & 168 & 8.207820 & 2.70375 & 24 & 0 & 0.00 \\
\hline loc wait & 8.5 & 6 & 168 & 10.567667 & 3.48111 & 6 & 2 & 58.02 \\
\hline loading1 & 8.5 & 1 & 3 & 25.724794 & 0.151322 & 1 & 0 & 15.13 \\
\hline loading2 & 8.5 & 1 & 2 & 27.768058 & 0.108894 & 1 & 0 & 10.89 \\
\hline loading3 & 8.5 & 1 & 4 & 23.269992 & 0.18251 & 1 & 0 & 18.25 \\
\hline unloading1 & 8.5 & 1 & 3 & 5.198367 & 0.0305786 & 1 & 0 & 3.06 \\
\hline unloading2 & 8.5 & 1 & 5 & 5.146350 & 0.0504544 & 1 & 0 & 5.05 \\
\hline unloading3 & 8.5 & 1 & 2 & 3.517150 & 0.0137927 & 1 & 0 & 1.38 \\
\hline unloading 4 & 8.5 & 1 & 5 & 5.632783 & 0.0552234 & 1 & 0 & 5.52 \\
\hline loading 4 & 8.5 & 1 & 5 & 24.681057 & 0.241971 & 1 & 0 & 24.20 \\
\hline loading5 & 8.5 & 1 & 0 & 0.000000 & 0 & 0 & 0 & 0.00 \\
\hline loading6 & 8.5 & 1 & 2 & 24.565392 & 0.0963349 & 1 & 0 & 9.63 \\
\hline loading7 & 8.5 & 1 & 3 & 25.068478 & 0.147462 & 1 & 0 & 14.75 \\
\hline loading8 & 8.5 & 1 & 3 & 22.567989 & 0.132753 & 1 & 0 & 13.28 \\
\hline loading 1 & 8.5 & 1 & 51 & 1.515637 & 0.151564 & 1 & 0 & 15.16 \\
\hline loading 2 & 8.5 & 1 & 49 & 1.541314 & 0.148087 & 1 & 0 & 14.81 \\
\hline loading9 & 8.5 & 1 & 1 & 19.511917 & 0.0382587 & 1 & 0 & 3.83 \\
\hline unloading5 & 8.5 & 1 & 0 & 0.000000 & 0 & 0 & 0 & 0.00 \\
\hline loading10 & 8.5 & 1 & 2 & 18.420533 & 0.0722374 & 1 & 0 & 7.22 \\
\hline loading11 & 8.5 & 1 & 1 & 24.603383 & 0.0482419 & 1 & 0 & 4.82 \\
\hline unloading6 & 8.5 & 1 & 0 & 0.000000 & 0 & 0 & 0 & 0.00 \\
\hline unloading 7 & 8.5 & 1 & 2 & 20.073842 & 0.0787209 & 1 & 0 & 7.87 \\
\hline unloading8 & 8.5 & 1 & 1 & 16.638017 & 0.0326236 & 1 & 0 & 3.26 \\
\hline unloading9 & 8.5 & 1 & 1 & 16.378717 & 0.0321151 & 1 & 0 & 3.21 \\
\hline
\end{tabular}

Gambar 4. Output Run Simulasi

Berdasarkan gambar 4, utilitas tempat bongkar muat barang berada pada sisi-sisi Hanggar, yaitu lokasi Utara, Barat, Timur dan Selatan Hanggar disajikan pada tabel 2.

Tabel 2. Utilitas Lokasi Simulasi Sistem Rill

\begin{tabular}{lcccc}
\hline \multicolumn{1}{c}{ Lokasi } & $\begin{array}{c}\text { Utilitas Hanggar } \\
(\%)\end{array}$ & $\begin{array}{c}\text { Jumlah Lokasi } \\
\text { Unloading }\end{array}$ & $\begin{array}{c}\text { Jumlah Lokasi } \\
\text { Loading }\end{array}$ & $\begin{array}{c}\text { Jumlah Lokasi } \\
\text { Parkir }\end{array}$ \\
\hline Utara Hanggar & 22.16 & 9 & 4 & 0 \\
Barat Hanggar & 13.12 & 4 & 8 & 2 \\
Timur Hanggar & 3.93 & 3 & 0 & 0 \\
Selatan Hanggar & 37.95 & 1 & 3 & 12 \\
\hline
\end{tabular}

Tabel 3. Rincian Hasil Simulasi Sistem Rill

\begin{tabular}{cccccccccc}
\hline Entity & Entry & $\begin{array}{c}\text { Total } \\
\text { exit }\end{array}$ & $\begin{array}{c}\text { Rata-rata } \\
\text { di dalam } \\
\text { sistem }\end{array}$ & $\begin{array}{c}\text { Rata-rata } \\
\text { perpinda } \\
\text { han }\end{array}$ & $\begin{array}{c}\text { Rata-rata } \\
\text { dalam } \\
\text { hanggar }\end{array}$ & $\begin{array}{c}\text { Rata- } \\
\text { rata } \\
\text { tertahan }\end{array}$ & $\begin{array}{c}\% \\
\text { perpinda } \\
\text { han }\end{array}$ & $\begin{array}{c}\text { \% dalam } \\
\text { hanggar }\end{array}$ & $\begin{array}{c}\% \\
\text { tertahan }\end{array}$ \\
\hline $\begin{array}{c}\text { Tonase } \\
\text { 1000-2000 } \\
\text { Tonase }\end{array}$ & 100 & 100 & 15.05 & 1.7 & 0.87 & 12.47 & 11.3 & 5.82 & 82.87 \\
$\begin{array}{c}2000-5000 \\
\text { Tonase }\end{array}$ & 8 & 56 & 103.8 & 2.11 & 89.9 & 11.78 & 2.04 & 86.61 & 11.35 \\
$\begin{array}{c}5000-7000 \\
\text { Jumlah }\end{array}$ & 168 & 164 & 23.07 & 1.46 & 18.78 & 2.82 & 6.36 & 81.4 & 12.24 \\
\hline
\end{tabular}

Dari tabel 3 dapat dilihat dari 168 kendaraan yang masuk, 164 kendaraan telah selesai melakukan bongkar atau muat, sedangkan 4 kendaraan masih tertahan di dalam pasar. Rata-rata utilitas Hanggar melayani 164 kendaraan 19,92\%. Kendaraan dengan beban 2000 - $5000 \mathrm{~kg}$ rata-rata di dalam hanggar 89,9 menit. Dibandingkan dengan kendaraan beban 5000 - $7000 \mathrm{~kg}$ lebih lama. Hal ini menunjukkan aktivitas 
kendaraan beban 2000 - $5000 \mathrm{~kg}$ tidak hanya bongkar muat saja tetapi melakukan aktivitas jual beli eceran.

\subsection{Verifikasi dan Validasi}

Tabel 4. Verifikasi Simulasi Sistem Rill

\begin{tabular}{|c|c|c|c|c|}
\hline No. & Kondisi & Aktual & Model & Keterangan \\
\hline 1. & Jumlah proses & 2 & 2 & Sesuai \\
\hline 2. & Jumlah lokasi loading & 15 & 15 & Sesuai \\
\hline 3. & Jumlah lokasi unloading & 17 & 17 & Sesuai \\
\hline 4. & Jumlah lokasi parkir & 17 & 17 & Sesuai \\
\hline 5. & $\begin{array}{l}\text { Jumlah kendaraan yang } \\
\text { masuk (per } 8 \text { jam) }\end{array}$ & 168 & 168 & Sesuai \\
\hline
\end{tabular}

Uji verifikasi model menunjukkan semua komponen penyusun sistem telah sesuai dengan sisstem riil.

Tabel 5. Validasi Simulasi Sistem Rill

\begin{tabular}{llcc}
\hline No. & Elemen kerja & Output aktual & Output model \\
\hline 1. & Utara hanggar & 18 & 24 \\
2. & Depan hanggar & 5 & 2 \\
3. & Belakang hanggar & 98 & 138 \\
\hline
\end{tabular}

Dari hasil uji validasi terdapat nilai sig. (2-tailed) sebesar 0.388 yaitu lebih besar dari 0.05 maka $\mathrm{H}_{0}$ diterima dan $\mathrm{H}_{1}$ ditolak, dapat diartikan bahwa tidak terdapat perbedaan pada output tiap proses bongkar muat antara rill dan model.

3.6 Replikasi

Tabel 6. Hasil Replikasi Simulasi Sistem Rill

\begin{tabular}{llccc}
\hline \multirow{2}{*}{ No. } & Elemen kerja & \multicolumn{2}{c}{ Output kendaraan } & \\
\cline { 3 - 4 } & & $\begin{array}{c}\text { Sebelum } \\
\text { replikasi }\end{array}$ & $\begin{array}{c}\text { Sesudah } \\
\text { replikasi }\end{array}$ & Std. Deviation \\
\hline 1. & Utara hanggar & 21 & 25 & 1.15 \\
2. & Depan hanggar & 2 & 1 & 0.815 \\
3. Belakang hanggar & 138 & 131 & 1.585 \\
Jumlah & 161 & 157 & 1.183 \\
\hline
\end{tabular}

Replikasi merupakan pengulangan dalam menjalankan model. Dengan banyaknya proses dan entiti dalam suatu model simulasi, ditambah dengan bilangan random sebagai input simulasi, maka hampir bisa dipastikan bahwa output suatu percobaan akan berbeda dengan percobaan lainnya (Nurhadi S., dkk., 2017).

\section{Perancangan Model Alternatif Usulan}

Alternatif Usulan 1 : pertama, lokasi utara hanggar sebelumnya adalah lokasi pedagang sayur, pada simulasi alernatif usulan 1 seluruh pedagang di pindahkan ke blok-blok pasar yang kosong dan tempat tersebut dijadikan tempat parkir serta tempat bongkar dan muat. Kedua, alur keluar masuk hanggar sebelumnya terdapat 2 jalur, maka pada simulasi alternatif usulan 1 ini alur keluar masuk hanggar di buat menjadi satu arah yang bertujuan untuk mengurangi kemacetan yang terjadi di sekitar hanggar pasar 
Giwangan. Rata-rata kendaraan beban 2000 - 5000 di dalam Hanggar 54,85 menit. Dibandingkan sistem riil rata-rata kendaraan di dalam Hanggar berkurang 35,05 menit. Jumlah kendaraan yang dapat dilayani oleh Hanggar juga menjadi 163 kendaraan. Utilitas Hanggar 18,45\%, menunjukkan bahwa peningkatan pelayanan menggunakan Hanggar dapat ditingkatkan dengan banyaknya jumlah kendaraan yang dilayani.

Alternatif Usulan 2 : pertama, lokasi utara hanggar sebelumnya adalah lokasi pedagang sayur, pada simulasi alernatif usulan 2 ini seluruh pedagang di pindahkan ke lokasi baru (Tempat Pemotongan Hewan) dan tempat tersebut dijadikan tempat parkir serta tempat bongkar muat. Kedua, alur aktivitas keluar masuk hanggar sebelumnya terdapat 2 jalur, pada simulasi alternatif usulan 2 ini alur keluar masuk hanggar di buat menjadi satu arah yang bertujuan untuk mengurangi kemacetan yang terjadi di sekitar hanggar pasar Giwangan. Ketiga, lokasi baru (TPH) dijadikan lokasi untuk pedagang sayur karena lebih dekat dengan Hanggar serta penambahan lokasi bongkar muat kendaraan. Jumlah kendaraan yang masuk sebesar 168 dan kendaraan yang keluar sebesar 168, dapat diartikan bahwa semua kendaraan yang masuk ke pasar Giwangan dapat melakukan proses bongkar muat. Jika di bandingkan dengan hasil simulasi sistem rill, terdapat perbedaan 4 kendaraan. Rata-rata persentase utilitas hanggar sebesar $16,13 \%$. Kondisi seperti ini dapat dikatakan lebih baik dari pada kondisi sistem rill.

\section{Pemilihan Alternatif}

Tabel 7. Hasil Perbandingan Persentase Utilitas Hanggar

\begin{tabular}{lccc}
\hline \multicolumn{1}{c}{ Lokasi } & Sistem riil $(\%)$ & Usulan 1 $(\%)$ & Usulan 2 (\%) \\
\hline Utara Hanggar & 22.16 & 22.04 & 21 \\
Barat Hanggar & 13.12 & 15.79 & 16.57 \\
Timur Hanggar & 3.93 & 8.41 & 7.27 \\
Selatan Hanggar & 37.95 & 27.57 & 19.7 \\
Rata-rata & 19.29 & 18.45 & 16.13 \\
\hline
\end{tabular}

Tabel 7 merupakan perbandingan persentase utilitas hanggar, dengan prilaku sistem yang sama didapat nilai rata-rata persentase utilitas hanggar terkecil yaitu pada alernatif usulan 2 sebesar $16.13 \%$. Nilai utilitas yang kecil bukan berarti nilai tersebut dikatakan buruk, tetapi dalam kasus pasar giwangan ini, hanggar mampu melayani kendaraan dengan jumlah yang lebih banyak sehingga utilitasnya akan meningkat.

\section{Kesimpulan}

Banyaknya kendaraan yang masuk dan dapat melakukan kegiatan bongkar muat dalam sebuah sistem menjadi indikator kualitas pelayanan sebuah tempat bongkar muat. Berdasarkan penelitian yang telah dilakukan, alternatif usulan 2 dapat meningkatkan pelayanan hanggar dari 97,62\% menjadi 100\%. Artinya jumlah kendaraan yang masuk ke dalam pasar Giwangan, dapat menyelesaikan bongkar muat di hanggar. Utilitas hanggar pada usulan 2 lebih kecil yang artinya semakin kecil nilai persentase utilitas lokasi bongkar muat seputar hanggar menandakan bahwa lokasi tersebut semakin siap digunakan apabila ada kendaraan yang akan melaksanakan bongkar muat. Persentase kecil disini juga menandakan bahwa arus lalu lintas juga semakin lancar dikarenakan tidak banyaknya kendaraan yang mengantri.

\section{Daftar Pustaka}

[1] Adeliana, V., Ridlo, M. A., \& Rochani, A. (2019). Evaluasi Manajemen Pasar Tradisional Berdasarkan Aspek Pelayanan Prima (Studi Kasus Pasar Tradisional Peterongan Semarang). Jurnal Planologi, 14(2), 175-186.

[2] Dimas, G. (2017). Kajian Aksesibilitas dalam Evaluasi Pasca Huni pada Pasar Sukaramai.

[3] Law, A. M., Kelton, W. D., \& Kelton, W. D. (2000). Simulation modeling and analysis (Vol. 3). New York: McGraw-Hill. 
[4] Selasdini, V., Barasa, L., \& Rs, W. (2018). Pengaruh Ketersediaan Utilisasi Alat Bongkar Muat Pelabuhan Terhadap Kinerja Produktivitas Di Pelabuhan Batu Ampar Batam. Meteor STIP Marunda, 11(2), 29-32.

[5] Prihati, Y. (2012). Simulasi dan pemodelan sistem antrian pelanggan di loket pembayaran rekening XYZ semarang. Jurnal Informatika, 3(3).

[6] Rahmanda, L. B., Widianty, D., \& Mahendra, M. (2017). Evaluasi Kinerja Ruas Jalan Akibat Aktivitas Samping Jalan Di Sekitar Pasar (Studi Kasus Ruas Jalan Bung Karno Kecamatan Kopang Kabupaten Lombok Tengah). Spektrum Sipil, 1(2), 121-132.

[7] Wibowo, A., \& Ramadian, D. (2011). Model simulasi kinerja produksi teh untuk minimisasi work-in-process. Jurnal Optimasi Sistim Industri (JOSI), 8(1).

[8] Amalia, P., \& Cahyati, N. (2020). Queue analysis of public healthcare system to reduce waiting time using flexsim 6.0. International Journal of Industrial Optimization, 1(2), 101110.

[9] Saputri, T., Nugraha, C., \& Amila, K. (2014). Model simulasi untuk pergerakan kendaraan pada ruang dua dimensi kontinu dengan pendekatan pemodelan berbasis agen. REKA INTEGRA, 2(4).

[10] Siswanto, N., Latiffianti, E., \& Wiratno, S., E. (2017). Simulasi Sistem Diskrit Implementasi dengan Software Arena. ITS Tekno Sains,

[11] Siagian, D. Dan Sugiarto. 2002. Metode Statistika Untuk Bisnis dan Ekonomi. PT. Gramedia Pustaka Utama. Jakarta.

[12] Simatupang, T. M. (1995). Pemodelan Sistem. Penerbit Kanida, Klaten. 
